Stigma Masyarakat Terhadap ODHA ..... (Konstantinus Hati, Zahroh S, Antono S)

\title{
Stigma Masyarakat Terhadap ODHA Di Kota Kupang Provinsi NTT
}

\author{
Konstantinus Hati*), Zahroh Shaluhiyah**) Antono Suryoputro**) \\ *) Dinas kesehatan Kabupaten Manggarai Provinsi Nusa Tenggara Timur \\ Korespondensi : konstantinushati@yahoo.coo.id \\ **) Magister Promosi Kesehatan FKM Universitas Diponegoro Semarang
}

\begin{abstract}
ABSTRAK
Menurut UNAIDS 2006 jumlah ODHA di dunia mencapai 39,4 juta, dewasa 37,2 juta, dan anak-anak <15 tahun 2,3 juta. Survey jaringan kerja ASIA-PASIFIK 2006 bahwa ODHA mengalami stigma dan diskriminasi dalam masyarakat sebesar 5-95\%. Survey BPS 2009 bahwa ODHA mengalami stigma dan diskriminasi dalam masyarakat sebesar 50-80\%. Di NTT sejak tahun 1997-2013, menurut KPA NTT ODHA yang meninggal 443 orang dan yang ditolak keluarga ada 8 orang. Penelitian ini bertujuan mengetahui faktor-faktor yang berpengaruh terhadap stigma yang diberikan masyarakat terhadap ODHA di Kota kupang. Metode: deskriptif survey analitik research pendekatan kuantitatif dengan rancangan cross secsional. Melakukan wawancara terhadap 382 Kepala Keluarga. Analisis data menggunakan uji univariat, bivariat dan multivariate. Hasil menunjukan terdapat 56,0\% stigma rendah dan $44.0 \%$ stigma tinggi terhadap ODHA. Variabel yang berpengaruh terhadap stigma masyarakat terhadap ODHA yaitu Pengetahuan, persepsi tentang HIVAIDS dan sikap KK, sikap keluarga besar, sikap tetangga, sikap tenaga kesehatan dan sikap tokoh masyarakat terhadap ODHA dengan tingkat probabilitas memberikan stigma terhadap ODHA sebesar $81.72 \%$.
\end{abstract}

Kata kunci: Stigma, Masyarakat, ODHA, Kota kupang.

\section{ABSTRACT}

Social Stigma among PLWHA in Kupang City East Nusa Tenggara: According to UNAIDS 2006 that PLWHA in the world reached 39.4 million, 37.2 million adults and children $<15$ years 2.3 million. ASIA-PACIFIC network survey in 2006 that PLWHA experience stigma and discrimination in the family, community and in health care by 5-95\%. BPS Research in 2009 that PLWHA experience stigma and discrimination within the family, community, neighbors, workplaces and health care by 50-80\%. NTT since 1997-2013, according to NTT KPA PLWHA who have died and 443 people were rejected by the family of 8 people. The aim of this study was to know about factors that influence a given society stigma against PLWHA in Kupang City. The method of this research is Analitic survey descriptive quantitative approach with cross secsional design. Conducted interviews with 382 head of familys. Analysis of test data using univariate, bivariate and multivariate. The results shows that here are 56,0\% low stigma and 44.0\% high stigma to PLWHA. The variables to determinant on the community stigma to PLWHA are Knowledge, perceptions about HIV/AIDS, the head of family attitudes, the big family attitude, the neighbor attitude, the attitude of health professionals, attitude of community leaders among PLHIV with a probability level of stigma towards PLWHA by providing $81.72 \%$.

Keywords: Stigma, Community, PLWHA, Kota Kupang 


\section{PENDAHULUAN}

Human Immunodefisiency Virus (HIV) adalah virus penyebab Acquired Immune Defisiency Sindrome (AIDS). Sedangkan AIDS adalah kumpulan gejala berbagai penyakit yang dapat menurunkan daya tahan tubuh manusia yang menyebabkan mudah terserang berbagai penyakit. $H I V$ menular lewat hubungan sexual dengan orang yang sudah menderita HIV/AIDS, jarum suntik yang bergantian dengan orang yang menderita HIV/AIDS pada penasun, mendapat transfuse darah dari penderita HIV/AIDS (Nasronudin, 2007). Epidemi penularan dan kematian karena HIV/AIDS semakin meningkat hampir disetiap Negara didunia. Hal ini terjadi karena permasalahan HIV/AIDS sangat komplek. Untuk memecahkan permasalahan HIV membutuhkan integritas lintas sektor maupun lintas program. Salah satu masalah yang paling besar didalamnya adalah persoalan stigma masyarakat terhadap ODHA.

Menurut UNAIDS 2006 kasus HIV/AIDS di dunia sudah mencapai 39,4 juta orang, dewasa sebanyak 37,2 juta orang dan anakanak dibawah usia 15 tahun sebanyak 2,3 juta orang (Kemenkes, RI.,2007). Menurut KPAN 2011, kasus terbaru AIDS Indonesia Januari sampai September 2011 sebesar 1805 kasus. Secara komulatif sampai dengan Juli 2011 sebesar 26.483 kasus. Terdapat $45,9 \%$ usia 20 -
29 tahun (BKKBN. RI.,2012). Survei Asia Pasific Network (APN) PLWHI, Juli tahun 2001 dan November 2002 menggambarkan $80 \%$ responden melaporkan adanya stigma dan diskriminatif di masyarakat dan 50\% dilayanan kesehatan (KPAN.,2011). Survei di Tujuh Provinsi di Indonesia tahun 2009 oleh BPS dan JOTHI terhadap 996 rumah tangga (Ruta) menunjukan bahwa terdapat $36 \%$ Rumah Tangga orang terinfeksi HIV pernah mengalami stigma dan diskriminasi dari tetangganya (KPAN.,2011\&Debora,I.,dkk, 2006).

Di NTT kasus komulatif HIV/AIDS sampai dengan Desember 2012 sebesar 1918 Kasus, HIV positif terjaring sebesar 837 kasus dan AIDS sebesar 1081 kasus, yang meninggal sebesar 443 kasus dan 8 kasus diantaranya ditolak oleh keluarga (KPAD NTT, 2013\&KPAD Manggarai, 2013). Dibeberapa kabupaten penderita HIV/AIDS mendapatkan obat di kabupaten lain karena alasan malu dengan keluarga dan masyarakat sekitar. Sikap stigma masyarakat terhadap HIV/AIDS sudah muncul sejak adanya penderita HIV/AIDS asal Adonara tahun 1997. Ketika penderita tersebut datang dari Malaysia, keluarganya menjadi malu karena ada rekomendasi bahwa sakit yang diderita adalah HIV/AIDS. Keluarga dan masyarakat di sekitar mengisolasinya sampai penderita itu meninggal. 
Dalam pasal 2 Undang-undang RI no. 36 tahun 2009 tentang Kesehatan menyebutkan Pembangunan kesehatan diselenggarakan dengan berasaskan perikemanusiaan, keseimbangan, manfaat, perlindungan, penghormatan terhadap hak dan kewajiban, keadilan, gender dan non diskriminatif dan norma-norma agama. Bentuk pelaksanaan dari undang-undang ini belum nampak, di Rumahrumah sakit se-NTT sejak tahun 2008 sudah ada keputusan agar pelayanan terhadap ODHA tidak boleh lagi ada perbedaan. Namun masih ada stigma dan diskriminasi terhadap ODHA. Hal ini membuat ODHA semakin tertekan, malu dan menutup diri tentang status HIV-nya (Kemenkes RI.,2012; UNAIDS,2012\&Kaldor, J,at.all.2000). Menurut Lawrence W.Green (2000) faktor yang mempengaruhi perilaku spesifik yaitu predisposing factors, enabling factors dan reinforcing factors. Predisposing factors meliputi pengetahuan, kepercayaan, nilai, sikap dan keyakinan. Enabling factors meliputi kemampuan untuk menjangkau sumber-sumber kesehatan, mengakses ke sarana kesehatan, peraturan pemerintah, prioritas pembangunan, komitment terhadap kesehatan, kesehatan berhubungan keterampilan. Reinforcing factors meliputi dukungan keluarga, teman, guru, atasan, pemberi layanan kesehatan, tokoh masyarakat dan pengambil keputusan. Uraian Green ini dapat diasumsikan bahwa orang berstigma terhadap ODHA disebakan karena kurangnya pengetahuan tentang HIV/AIDS, adanya persepsi negative tentang HIV/AIDS, dan adanya peran yang kurang mendukung dari keluarga, teman, guru, tenaga kesehatan, pemerintah dan tokoh masyarakat.

\section{Metode Penelitian}

Penelitian ini adalah survei deskriptif analitik pendekatan kuantitatif rancangan Cross seccional. Melakukan wawancara dengan menggunakan kuisioner terhadap 382 kepala keluarga sebagai responden yang bertujuan mengetahui faktor-faktor yang berpengaruh terhadap stigma yang diberikan masyarakat terhadap ODHA di Kota Kupang dengan populasi sebesar 54960 KK. (Arikunto, 2000). Pengambilan sample menggunakan tehnik multistage proporsional random sampling. Unit sampel yang pertama disebut Primary Sampling Unit (PSU). Bila PSU (Primary sampling unit) adalah kecamatan maka sampelnya adalah lurah, bila PSU (Primery sampling unit) adalah Lurah maka sampelnya adalah RT dan bila $P S U$ (Primery sampling unit) adalah RT maka sampelnya adalah kepala keluarga. Penentuan proporsi besar sampel setiap kecamatan tergantung jumlah KK dalam kecamatan dibagi besar populasi lalu dikalikan dengan besar sampel. Setiap kecamatan mengambil salah 
satu lurah secara acak sederhana dan setiap lurah mengambil salah satu RT secara acak sederhana demikian juga dalam satu RT mengambil KK sebagai responden secara acak sederhana (Lemeshow, 1997 \& Sugiyono, 2010).

\section{HASIL DAN PEMBAHASAN}

\section{Karakteristik responden}

Responden dalam penelitian ini adalah kepala Keluarga. Umur termuda 17 tahun dan umur tertua 82 tahun dengan modus 40 tahun, laki-laki berjumlah $81.7 \%$ dan perempuan $18.3 \%$, rata-rata pendidikan responden tamat SMP dan SMU. Kategori pendidikan tinggi $36.1 \%$ dan pendidikan rendah $63.9 \%$, Responden yang tidak bekerja sebanyak 71 orang (18.6\%) dan yang bekerja sebanyak 311 orang $(81.4 \%)$, sudah menikah lebih banyak (85.1\%) dan yang belum menikah (14.9\%). Responden yang tidak mempunyai kedudukan dalam masyarakat lebih banyak yaitu 218 orang $(57.1 \%)$ dari pada yang mempunyai kedudukan yaitu 164 orang (42.9\%).

\section{Stigma Yang Diberikan Masyarakat} Terhadap ODHA Di Kota Kupang.

Hasil penelitian menunjukan bahwa terdapat $56,0 \%$ responden memberikan stigma rendah dan $44.0 \%$ responden memberikan stigma tinggi terhadap ODHA. Gambaran stigma masyarakat terhadap ODHA yaitu terdapat $26.7 \%$ responden menyatakan ODHA diisolasi dalam keluarga, terdapat $19.1 \%$ menyatakan ODHA tidak boleh ikut rapat di RT,RW, Lurah, Camat, dan rumah ibadat, terdapat $18.6 \%$ menyatakan ODHA tidak boleh terima ditempat kerja, terdapat $23.3 \%$ menyatakan tidak boleh berciuman, bersalaman, duduk bersama, dan makan bersama dengan ODHA, terdapat $55.8 \%$ menyatakan ODHA harus diisolasi di Rumah sakit dan terdapat $29.3 \%$ responden menyatakan sebagai guru harus waspada dalam menerima murid baru yang terinfeksi $H I V$ karena takut menular kepada murid yang lain. Tabel 1. distribusi stigma yang diberikan masyarakat terhadap ODHA.

No. $\quad$ Stigna Masyarakat terhadap ODHA $\quad$ Frekuensi (f) $\quad$ Prosentase (\%)

\begin{tabular}{llcc}
\hline 1. & Stigma tinggi $($ skor stigma< 17.0$)$ & 168 & 44.0 \\
2. & Stigma rendah $($ skor stigma $\geq 17.0)$ & 214 & 56.0 \\
\hline & Total & 382 & 100 \\
\hline
\end{tabular}

Median: 17.0

Stigma HIV/AIDS yang diberikan Timur juga dipengaruhi oleh faktor-faktor masyarakat terhadap ODHA di Nusa Tenggara sosial budaya masyarakat (KPAD.NTT,2013; 
KPAD.Kab.Manggarai,2013\&Goffmen,1963). Stigma terhadap ODHA yang berasal dari kalangan orang berpendidikan di Kota kupang muncul disebabkan oleh karena pengaruh budaya, norma masyarakat, pandangan agama yang melekat pada orang yang berpengetahuan. Sedangkan masyarakat luas belum berada pada kondisi pemahaman kemajuan yang bersifat global. Penelitian Pam O'Connor, dkk, (2011) di Mumbai bahwa stigma dan diskriminasi terhadap orang dengan HIV/AIDS terjadi dalam keluarga, tetangga, masyarakat, tempat kerja,

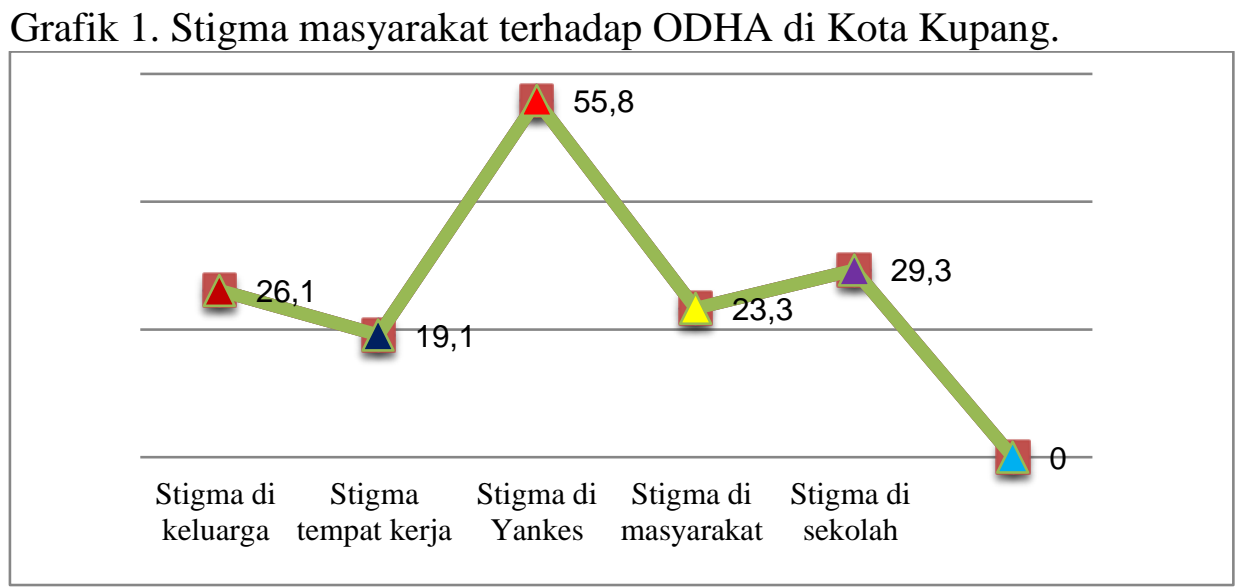

Menurut Goffmen (1963) yang dikutip dijelaskan bahwa stigma terhadap orang oleh Pamor dan Anggleton (2003) mengatakan dengan HIV/AIDS itu berasal dari masyarakat bahwa stigma itu berasal dari masyarakat. yang memandang atau menilai ODHA itu masyarakat memberikan stigma kepada orang adalah orang yang melanggar norma sosial. yang melanggar norma sosial. Masyarakat Menurut Mayor B dan O'Brien, (2005) memberikan identitas khusus bagi orang yang masyarakat yang memiliki keyakinan terhadap melanggar norma sosial. Kemudian mereka budaya, norma masyarakat yang kuat serta membedakan dalam kelompok terstigma dan beragama dengan fanatik akan memberikan kelompok normal dalam masyarakat stigma terhadap orang yang melanggar norma (Wood,at.all.,2005\&Goffmen,1963). lebih kuat juga (Mayor, B.\& O’Brien,2004).

Berdasarkan pendapat Goffmen, dapat 
Di Kota Kupang keyakinan terhadap budaya, norma dan agamanya masih sangat kuat. Walaupun tingkat pendidikan masyarakatnya rata-rata tamat SMU dan SLTP tetapi mereka masih berada pada era ambivalensi artinya era yang masih memegang keyakinan terhadap budaya, norma dan agma dengan era yang menuntut mereka harus mengikuti perkembangan kemajuan tekhnologi yang canggih. Belum sepenuhnya masyarakat berpendidikan di Kota Kupang untuk melepaskan pengaruh budaya dalam masyarakat. Hal ini mengakibatkan adanya stigma ODHA dari kalangan orang yang berpendidikan. Maka dapatlah dikatakan bahwa stigma terhadap ODHA di Kota Kupang dipengaruhi kuat oleh budaya, norma dan agama.

Dalam penelitian yang dilakukan Yuyun, dkk, (2011) tentang faktor-faktor yang mempengaruhi kepatuhan ODHA minum $A R V$ di kota Bandung, Cimahi (studi kualitatif) mendapatkan hasil bahwa sebagian besar responden mengatakan bahwa mereka takut diketahui status $H I V$ mereka oleh orang lain (Yuyun, dkk, 2011). Yuyun menjelaskan bahwa ketakutan ODHA itu terjadi karena masih adanya stigma HIV/AIDS pada kalangan masyarakat. Apabila masyarakat tahu bahwa mereka HIV positip maka pasti saja masyarakat menolak mereka. Hasil penelitian Yuyun, dkk (2011) menjelaskan bahwa Stigma mengganggu kehidupan ODHA. Selanjutnya Yuyun dkk.,menjelaskan bahwa beberapa faktor pendukung bagi ODHA agar tetap patuh minum obat dalam kondisi distigma adalah kerja sama dengan tenaga kesehatan agar tetap merahasiakan statusnya, dukungan keluarga, dukungan anak-anak, dukungan teman sebaya, dukungan kelompok sebaya, dukungan tetangga dan dukungan LSM. Stigma adalah tindakan memberikan label sosial yang bertujuan untuk memisahkan atau mendiskreditkan seseorang atau sekelompok orang dengan cap atau pandangan buruk. Dalam prakteknya, stigma mengakibatkan tindakan diskriminasi yaitu tindakan tidak mengakui atau tidak mengupayakan pemenuhan hak-hak dasar indvidu atau kelompok sebagaimana selayaknya sebagai manusia yang bermartabat. 
Tabel 2. Hasil tabulasi silang antara karakteristik responden dan stigma terhadap ODHA.

\begin{tabular}{|c|c|c|c|c|c|c|c|c|c|}
\hline \multirow{3}{*}{ Variabel } & \multirow{3}{*}{ Kategori } & \multirow{3}{*}{$\begin{array}{l}p \text {-value } \\
\text { hasil }\end{array}$} & \multicolumn{4}{|c|}{ Kategori stigma } & \multirow{2}{*}{\multicolumn{2}{|c|}{ Total }} & \multirow{3}{*}{ Keterangan } \\
\hline & & & \multicolumn{2}{|c|}{ Stigma tinggi } & \multicolumn{2}{|c|}{ Stigma rendah } & & & \\
\hline & & & $\mathrm{F}$ & $\%$ & $\mathrm{~F}$ & $\%$ & $\mathrm{f}$ & $\%$ & \\
\hline \multirow{2}{*}{ Umur } & $<36$ tahun & \multirow{2}{*}{0,931} & 80 & 43.5 & 104 & 56.5 & 184 & 100 & Tidak ada \\
\hline & $>/ 36$ tahun & & 88 & 44.4 & 110 & 55.6 & 198 & 100 & hubungan \\
\hline \multirow{2}{*}{ Jenis kelamin } & Laki-laki & \multirow{2}{*}{0,027} & 146 & 46.8 & 166 & 53.2 & 312 & 100 & \\
\hline & Perempuan & & 22 & 31.4 & 48 & 68.6 & 70 & 100 & Ada hubungan \\
\hline \multirow{2}{*}{ Pendidikan } & Rendah & \multirow{2}{*}{0,184} & 114 & 46.7 & 130 & 53.3 & 244 & 100 & Tidak ada \\
\hline & Tinggi & & 54 & 39.1 & 84 & 60.9 & 138 & 100 & hubungan \\
\hline \multirow{2}{*}{ Pekerjaan } & Tidak bekerja & \multirow{2}{*}{0,324} & 27 & 38.0 & 44 & 62.0 & 71 & 100 & Tidak ada \\
\hline & Bekerja & & 141 & 45.3 & 170 & 54.7 & 311 & 100 & Hubungan \\
\hline \multirow{3}{*}{$\begin{array}{l}\text { Status } \\
\text { perkawinan }\end{array}$} & Belum menikah & \multirow{3}{*}{0,321} & 29 & 50.9 & 28 & 49.1 & 57 & 100 & Tidak ada \\
\hline & menikah & & 139 & 42.8 & 186 & 57.2 & 325 & 100 & Hubungan \\
\hline & Tidak ada & & 96 & 44.0 & 222 & 56.0 & 218 & 100 & \\
\hline $\begin{array}{l}\text { Status } \\
\text { kedudukan }\end{array}$ & $\begin{array}{l}\text { kedudukan } \\
\text { Mempunyai } \\
\text { kedudukan }\end{array}$ & 1,000 & 72 & 43.9 & 92 & 56.1 & 164 & 100 & $\begin{array}{l}\text { Tidak ada } \\
\text { Hubungan }\end{array}$ \\
\hline
\end{tabular}

Stigma dan diskriminasi terjadi karena adanya persepsi bahwa mereka dianggap sebagai musuh, penyakit, elemen masyarakat yang memalukan, atau mereka yang tidak taat terhadap norma masyarakat dan agama yang berlaku. Implikasi dari stigma dan diskriminasi bukan hanya pada diri orang atau kelompok tertentu tetapi juga pada keluarga dan pihak-pihak yang terkait dengan kehidupan mereka (Kemenkes.RI, 2012). Stigma yang diberikan masyarakat terhadap ODHA adalah berbentuk cap yaitu ODHA itu Narkoba, ODHA itu pasti PSK, ODHA itu pasti moralnya tidak baik, HIV-AIDS itu penyakit berbahaya, $H I V-A I D S$ itu penyakit amoral, $H I V$-AIDS itu penyakit orang narkoba dan PSK. Stigma adalah hal-hal yang membawa aib, hal yang memalukan, sesuatu dimana seseorang menjadi rendah hati, malu dan takut karena sesuatu. Dari pengertian ini dapat dikatakan bahwa ODHA yang distigma masyarakat pasti merasa malu, merasa dikucilkan, merasa direndahkan dimata masyarakat lain. Oleh karena itulah mereka menyendiri, menyembunyikan diri mereka dari orang lain.

\section{Pengetahuan responden tentang}

\section{HIV/AIDS.}

Hasil penelitian menunjukan bahwa responden yang memiliki pengetahuan kurang memberikan stigma tinggi sebesar $75 \%$ dan stigma rendah sebesar $24.7 \%$, sedangkan pada responden yang memiliki pengetahuan baik memberikan stigma tinggi sebesar $33.9 \%$ dan stigma rendah sebesar $66.1 \%$. Hasil uji $C h i$ Squre nilai $p=0.000(p<0.05)$ sehingga $\mathrm{H} 0$ ditolak dan Ha diterima artinya terbukti ada hubungan antara pengetahuan dengan stigma yang diberikan masyarakat terhadap ODHA. Hasil uji regresi ganda dengan nilai $p=0.020$ 
dengan EXP.B=2.420 artinya sikap tentang $H I V-A I D S$ berpengaruh terhadap stigma yang diberikan masyarakat terhadap ODHA dengan kekuatan probabilitas 2.420. Hal ini berarti jika seseorang mempunyai pengetahuan baik tentang $H I V$-AIDS mempunyai kemungkinan berpengaruh mengurangi stigma sebesar 2 kali dibandingkan jika seseorang mempunyai pengetahuan kurang tentang HIV-AIDS. Sebaliknya jika seseorang mempunyai pengetahuan kurang tentang $H I V-A I D S$ maka akan berpengaruh memberikan stigma terhadap ODHA sebesar 2 kali lebih besar dibandingkan dengan mereka yang memiliki pengetahuan baik terhadap ODHA.

Menurut penelitian Soedarjatmika (2008) didapatkan bahwa pengetahuan berpengaruh terhadap stigma diakibatkan oleh kurangnya pemahaman terhadap penyakit tersebut. Sedangkan menurut penelitian Mahendra at al, (2007) dan penelitian Pratikno, (2008) dalam Tri P.,dkk mengatakan bahwa terbukti adanya stigma dan diskriminasi terhadap ODHA dipengaruhi oleh tingkat pengetahuan dan persepsi tenaga kesehatan yang kurang tentang HIV-AIDS (Paryati,dkk.,2013).

Pengetahuan merupakan salah satu faktor yang mempengaruhi seseorang dapat memberikan stigma kepada ODHA. Diduga bahwa semakin baik pengetahuan seseorang tentang HIV-AIDS maka semakin rendah pula stigma yang diberikan terhadap ODHA dan bahkan tidak memberikan stigma kepada ODHA. Menurut Notoadmojo, (2003) mengatakan bahwa fungsi dari pengetahuan adalah mendorong individu untuk mengerti dengan pengalaman-pengalamannya untuk memperoleh pengetahuan. Elemen-elemen dari pengalamannya yang tidak konsisten dengan apa yang diketahui oleh individu akan disusun kembali atau diubah sedemikian rupa hingga menjadi konsisten (Notoadmojo, S, 2009).

Menurut Bradley (2009) Dalam penelitian yang dilakukan oleh Tri Paryati didapatkan bahwa Pengetahuan tentang HIV/AIDS sangat mempengaruhi bagaimana individu tersebut akan bersikap terhadap penderita HIV/AIDS. Menurut Chase dan Aggleton (2001) mengatakan bahwa salah satu penyebab terjadinya stigma adalah mis-informasi mengenai bagaimana $H I V$ ditransmimisikan (UNAIDS, 2000). Hal ini berarti masyarakat memberikan stigma atau tidaknya kepada ODHA juga sangat dipengaruhi oleh bagaimana pemahaman mereka terhadap ODHA.

\section{Persepsi responden tentang $H I V$-AIDS.}

Dalam penelitian ini didapatkan bahwa $70 \%$ responden yang memiliki persepsi kurang memberikan stigma tinggi terhadap ODHA. Sedangkan responden yang memiliki persepsi 
baik memberikan stigma tinggi terhadap terbukti ada hubungan antara persepsi tentang ODHA sebesar 26.4 Berdasarkan hasil uji Chi $H I V-A I D S$ dengan stigma yang diberikan Square diperoleh hasil p-value 0.000 artinya terbukti ada hubungan antara persepsi tentang $H I V-A I D S$ dengan stigma yang diberikan masyarakat terhadap ODHA. Persepsi merupakan salah satu faktor yang masyarakat terhadap ODHA. Hasil uji regresi ganda dengan nilai $p=0.001$ dengan mempengaruhi seseorang memberikan stigma terhadap ODHA. Menurut penelitian EXP.B $=2.861$ artinya persepsi tentang $H I V$ AIDS berpengaruh terhadap stigma yang diberikan masyarakat terhadap ODHA dengan kekuatan probabilitas 2.861. Hal ini berarti jika seseorang mempunyai persepsi kurang tentang $H I V$-AIDS mempunyai peluang Soedarjatmika, (2008) didapatkan bahwa persepsi berpengaruh terhadap stigma diakibatkan oleh kurangnya pemahaman terhadap penyakit tersebut. Sedangkan menurut penelitian Mahendra at.all., (2007) dan penelitian Pratikno, (2008) dalam Tri P.,dkk mengatakan bahwa terbukti adanya memberikan stigma sebesar 2.861 kali stigma dan diskriminasi terhadap ODHA dibandingkan jika seseorang mempunyai dipengaruhi oleh tingkat pengetahuan dan persepsi baik tentang $H I V-A I D S$. Penelitian persepsi tenaga kesehatan yang kurang tentang sebelumnya yang dilakukan oleh Cock, dkk HIV-AIDS. dan Herek (2002) yang mengatakan bahwa Tabel 3. Hasil Analisis Multivariat.

\begin{tabular}{|c|c|c|c|c|c|c|}
\hline \multirow{2}{*}{$\begin{array}{l}\mathrm{N} \\
0 .\end{array}$} & \multirow[t]{2}{*}{ Variabel } & \multirow[t]{2}{*}{$B$} & \multirow[t]{2}{*}{ Nilai $p$} & \multirow{2}{*}{$\begin{array}{c}\operatorname{Exp} . B \\
(O R)\end{array}$} & \multicolumn{2}{|c|}{ 95\% CI.for Exp.B } \\
\hline & & & & & Lower & Upper \\
\hline 1. & Status kawin & 0.725 & 0.072 & 2.066 & 0.938 & 4.547 \\
\hline 2. & Status kedudukan dlm masyarakat. & 0.529 & 0.091 & 1.697 & 0.919 & 3.136 \\
\hline 3. & Pengetahuan tentang HIV-AIDS. *) & 0.884 & 0.020 & 2.420 & 1.146 & 5.111 \\
\hline 4. & Persepsi tentang HIV-AIDS. *) & 1.035 & 0.001 & 2.816 & 1.532 & 5.174 \\
\hline 5. & Sikap terhadap ODHA.*) & 0.665 & 0.039 & 1.945 & 1.033 & 3.661 \\
\hline 6. & $\begin{array}{l}\text { Sikap keluarga besar terhadap } \\
\text { ODHA.*) }\end{array}$ & 1.126 & 0.001 & 3.083 & 1.609 & 5.907 \\
\hline 7. & Sikap tetangga terhdp ODHA.*) & 0.700 & 0.038 & 2.014 & 1.038 & 3.909 \\
\hline 8. & $\begin{array}{l}\text { Sikap tenaga kesehatan terhadap } \\
\text { ODHA.*) }\end{array}$ & 1.163 & 0.001 & 3.199 & 1.615 & 6.336 \\
\hline 9. & $\begin{array}{l}\text { Sikap tokoh masyarakat terhdp } \\
\text { ODHA.*) }\end{array}$ & 1.576 & 0.000 & 4.834 & 2.194 & 10.646 \\
\hline
\end{tabular}

Constant: $B:-5.647$ Probabilitas pengaruh $\left.=81,72 \% .^{*}\right)=$ variabel yang berpengaruh 


\section{Sikap responden terhadap ODHA.}

Sikap merupakan salah satu faktor penting mempengaruhi stigma yang diberikan masyarakat terhadap ODHA. Menurut Thurston dan Chave (dalam Mitchell,1990) ditulis Wawan dan Dewi, 2011 mengatakan sikap adalah keseluruhan dari kecendrungan dan perasaan, curiga atau bias, asumsi-asumsi, ide-ide, ketakutan-ketakutan, tantangantantangan, dan keyakinan-keyakinan manusia mengenai topik tertentu (Wawan\&Dewi,2011). Berdasarkan definisi ini dapat dipahami bahwa sikap terhadap HIVAIDS merupakan keseluruhan dari kecendrungan dan perasaan, curiga atau bias, asumsi, ide, ketakutan, tantangan dan keyakinan seseorang tentang HIV-AIDS.

Dalam penelitian ini didapatkan bahwa responden yang mempunyai sikap kurang memberikan stigma tinggi terhadap ODHA sebesar $70.6 \%$ dan stigma rendah sebesar 29.4\%, sedangkan pada responden yang mempunyai sikap baik memberikan stigma tinggi sebesar $30.9 \%$ dan stigma rendah sebesar 69.1\%. Berdasarkan uji Chi Squre sikap dengan nilai $p=0.000(p<0.05)$ artinya terbukti ada hubungan antara sikap tentang HIV-AIDS dengan stigma yang diberikan masyarakat terhadap ODHA. Hasil uji regresi logistik ganda didapatkan nilai $p=0.039$ $(p<0.05)$ dengan nilai EXP.B $(O R)=1.945$, hal ini berarti sikap terhadap HIV-AIDS mempunyai pengaruh yang signifikan terhadap stigma yang diberikan masyarakat terhadap ODHA. Sikap merupakan respons seseorang terhadap objek yang dilihatnya. Bentuk respons setiap orang terhadap objek yang ada tergantung pengalaman dan pengetahuan yang dimilikinya. Dari pengertian di atas dapat disimpulkan bahwa sikap terhadap HIV-AIDS adalah kondisi mental dan neural yang diperoleh dari pengalaman tentang HIV-AIDS, yang mengarah dan secara dinamis mempengaruhi respon-respon individu terhadap penyakit HIV-AIDS atau terhadap ODHA. Hal ini berarti semakin baik pengalaman orang tentang HIV-AIDS semakin baik pula responnya terhadap ODHA. Green (2000) mengatakan bahwa sikap seseorang juga sangat dipengaruhi oleh kondisi lingkungan dan sosial budaya. Pendapat green ini dapat diartikan bahwa orang memandang sesuatu itu baik atau buruk juga dipengaruhi oleh lingkungan sekitar. Selain itu kondisi dan situasi yang dipengaruhi kekuatan norma sosial yang di mana seseorang tinggal.

\section{Sikap keluarga besar terhadap ODHA.}

Dalam penelitian ini didapatkan bahwa pada responden yang mengatakan sikap keluarga kurang terhadap ODHA memberikan stigma tinggi sebesar $77.5 \%$ 
dan stigma rendah sebesar $22.5 \%$, sedangkan pada responden yang menagatakan keluarga baik memberikan stigma tinggi sebesar $26.9 \%$ dan stigma rendah sebesar $73.1 \%$. Berdasarkan hasil uji Chi Squere nilai $p=0.000 \quad(p<0.05)$ artinya terbukti ada hubungan antara sikap keluarga besar terhadap ODHA dengan stigma yang diberikan masyarakat terhadap ODHA. Hasil uji regresi logistik ganda $p=0.001(p<0.05)$ dengan EXP.B $(O R)=3.083$, artinya terbukti ada pengaruh secara significancy sikap keluarga besar terhadap stigma yang diberikan masyarakat terhadap ODHA.

Keluarga merupakan unit terkecil masyarakat yang mempunyai interaksi yang sangat kuat secara bio-psiko-sosial-kultural antara individu dengan individu di dalamnya. Skiner, (1999) mengatakan bahwa keluarga mempunyai fungsi melindungi, memelihara, mengasuh serta merawat anggota keluarganya. Hal ini berarti dukungan keluarga sangat penting untuk memberikan semangat hidup bagi ODHA dan mengurangi stigma yang diberikan masyarakat terhadap ODHA. Sikap keluarga sangatlah penting terhadap ODHA agar tetap bisa mempertahankan kesehatannya dan hidupnya dalam kehidupan bermasyarakat. Menurut Falk (2001) mengatakan bahwa kita dan semua masyarakat mempunyai kesempatan yang sama untuk mengstigmatisasi terhadap beberapa kondisi dan beberapa perilaku tertentu karena itu salah satu bentuk solidaritas kelompok dengan menggambarkan orang luar dari orang dalam (Yuyun,dkk.,2011). Hal ini berarti semua masyarakat termasuk keluarga mempunyai kesempatan untuk berstigma terhadap ODHA. Untuk mengatasi agar ODHA tidak patah semangat maka keluarga seharusnya memberikan dukungan terhadap ODHA agar dia tidak merasa terstigma atau agar masyarakat lain tidak ikut memberikan stigma terhadap ODHA.

\section{Sikap tetangga terhadap ODHA.}

Dalam penelitian ini didapatkan bahwa pada responden yang mengatakan sikap tetangga kurang memberikan stigma tinggi terhadap ODHA sebesar $76.6 \%$ dan stigma rendah sebesar $23.4 \%$, sedangkan pada sikap tetangga baik memberikan stigma tinggi sebesar $24.1 \%$ dan stigma rendah sebesar 75.9\%. Berdasarkan hasil uji Chi Squre nilai $p=0.000 \quad(<0.05)$ artinya terbukti ada hubungan antara sikap tetangga dengan stigma yang diberikan masyarakat terhadap ODHA. Hasil uji regresi logistik ganda nilai $p=0.038$ $(p<0.05)$ dengan EXP.B $(O R)=2.014$ artinya terbukti ada pengaruh yang significant sikap tetangga terhadap ODHA dengan stigma yang 
diberikan masyarakat terhadap ODHA. Hal ini berarti tetangga yang mempunyai sikap kurang terhadap ODHA mempunyai peluang memberikan stigma terhadap ODHA sebesar 2.014 kali lebih besar dari pada tetangga yang mempunyai sikap baik.

Hasil penelitian O'Connor, dkk, (2011) di Afrika bahwa ODHA mendapat stigma dan diskriminasi dari tetangga. Tetangga merupakan bagian dari masyarakat yang juga mempunyai peluang yang sama untuk mengstigma ODHA. Menurut Levin dan Van Laar (2004) mengatakan bahwa induvidu aktif mengatasi stigma dengan cara yang berbedabeda diseluruh kelompok terstigma ketika individu atau kelompok terstigma, setiap waktu dalam segala situasi. Bentuk stigma yang dimaksukan adalah dikucilkan oleh teangga, dikucilkan oleh keluarga, devaluasi, ditolak, dihina dan dihindari oleh tetangga dan masyarakat (Yuyun,dkk.,2011). Hal ini berarti bahwa kondisi interaksi dalam kehidupan antara teman, keluarga, tetangga dan masyarakat mempengaruhi orang agar bisa melakukan perilaku spesifik.

Sikap tenaga kesehatan terhadap ODHA.

Dalam penelitian ini didapatkan bahwa pada responden yang mengatakan sikap tenaga kesehatan kurang memberikan stigma tinggi terhadap ODHA sebesar $79.6 \%$ dan stigma rendah sebesar $20.4 \%$, sedangkan pada sikap tenaga kesehatan baik memberikan stigma tinggi sebesar $29.0 \%$ dan stigma rendah sebesar $71.0 \%$. Berdasarkan hasil uji Chi Squere nilai $p=0.000(p<0.05)$ berarti terbukti ada hubungan antara sikap tenaga kesehatan dengan stigma yang diberikan masyarakat terhadap ODHA. Hasil uji regresi logistik ganda $p=0.001 \quad(p<0.05) \quad$ dengan nilai EXP.B $(O R)=3.199$ yang berarti terbukti adanya pengaruh yang significant antara sikap tenaga kesehatan terhadap stigma yang diberikan masyarakat terhadap ODHA. Penelitian Widyawati, (2009) bahwa terbukti adanya pengaruh dukungan tenaga kesehatan terhadap sikap ibu hamil terhadap HIV-AIDS dan VCT. Menurut penelitian Pratikno (2008), menunjukkan hasil bahwa adanya stigma dan diskriminasi pada ODHA oleh petugas kesehatan dipengaruhi oleh pengetahuan dan persepsi petugas kesehatan tentang HIV/AIDS.

Tenaga kesehatan merupakan pemberi layanan kesehatan terhadap ODHA yang pada kenyataannya selalu berhubungan dengan penderita $H I V$-AIDS dalam pelayanan seharihari. Tenaga kesehatan adalah sumber informasi kesehatan yang benar dan mempunyai kekuatan tersendiri bagi ODHA agar selalu semangat berobat dan mengontrol kesehatannya. Maka jika orang kesehatan memberikan stigma kepada ODHA maka akan mematah semangat hidup ODHA. Green 
(2000), mengatakan bahwa dukungan tenaga kesehatan merupakan faktor penguat (reinforce) terhadap perilaku spesifik kesehatan seseorang. Dalam hal ini tenaga kesehatan merupakan faktor penguat bagi ODHA agar tetap semangat dalam hidup.

Sikap tokoh masyarakat terhadap ODHA.

Dalam penelitian ini didapatkan bahwa pada sikap tokoh masyarakat kurang terhadap ODHA memberikan stigma tinggi terhadap ODHA sebesar $87.8 \%$ dan stigma rendah sebesar $12.2 \%$, sedangkan pada responden yang mengatakan sikap tokoh masyarakat baik memberikan stigma tinggi sebesar $28.9 \%$ dan stigma rendah sebesar $71.1 \%$. Berdasarkan hasil uji Chi Square nilai $p=0.000(p<0.05)$ artinya terdapat bukti bahwa ada hubungan antara sikap tokoh masyarakat dengan stigma yang diberikan masyarakat terhadap ODHA. Hasil uji regresi logistik ganda nilai $p=0.000$ $(p<0.05)$ dan EXP.B $(O R)=4.834$ artinya terbukti ada pengaruh yang sangat significant antara sikap tokoh masyarakat terhadap stigma yang diberikan masyarakat terhadap ODHA dengan probability 4.834. Hal ini artinya jika tokoh masyarakat mempunyai sikap kurang terhadap ODHA maka akan mempunyai peluang memberikan stigma terhadap ODHA sebesar 4.834 kali lebih besar dari pada jika tokoh masyarakat mempunyai sikap baik terhadap ODHA.
Menurut penelitian yang dilakukan $\mathrm{Li} \mathrm{Li}$, at al, (2009) di China didapatkan bahwa dukungan institusi mempunyai pengaruh yang signifikan terhadap diskriminasi pada ODHA oleh institusi pemerintah, tokoh masyarakat dan petugas kesehatan (Paryati,dkk.,2013). Penelitian ini mempunyai hasil yang sama dengan penelitian Widyawati, (2009) mengatakan terbukti adanya pengaruh dukungan tokoh masyarakat, keluarga, teman dan informasi lain terhadap perilaku ibu hamil tentang HIV-AIDS dan VCT.

Green (2000), mengatakan bahwa tokoh masyarakat merupakan salah satu faktor pendukung dalam merubah perilaku masyarakat. Hal ini berarti bahwa tokoh masyarakat merupakan corong yang mempunyai power bagi semua masyarakat. apa pun hal yang diucapkan tokoh masyarakat tentang ODHA akan berpengaruh terhadap sikap masyarakat tersebut terhadap ODHA. Bagaimana pun halnya, tokoh masyarakat akan memiliki dukungan baik terhadap ODHA disebabkan karena pemahaman tokoh masyarakat tentang ODHA sudah benar. Oleh karena itu sangatlah penting peningkatan pengetahun tentang HIV/AIDS bagi tokoh masyarakat.

\section{SIMPULAN}

Sikap masyarakat Kota Kupang terhadap ODHA masih dikategorikan baik walaupun 
terdapat $44.0 \%$ responden yang memberikan stigma tinggi. Masih terdapat stigma sebesar $26.1 \%$ di keluarga, $19.1 \%$ di tempat kerja, $55.8 \%$ di yankes, $23.3 \%$ di masyarakat dan $29.3 \%$ di sekolah. Sebesar $37.7 \%$ responden mengatakan bahwa ODHA seharusnya diisolasi bila dirawat di rumah sakit, sebesar $38.2 \%$ perawatan terhadap ODHA harus menggunakan perlindungan yang ekstra awas tertular HIV, sebesar $55.8 \%$ mengatakan bahwa tindakan isolasi ODHA itu merupakan keputusan yang paling tepat agar bisa membedakan penderita $H I V$ dengan penderita lain.

Faktor-faktor yang berpengaruh terhadap stigma yang diberikan masyarakat terhadap ODHA yaitu Pengetahuan kepala keluarga tentang HIV/AIDS, Persepsi kepala keluarga tentang HIV/AIDS, Sikap kepala keluarga terhadap ODHA, Sikap keluarga besar terhadap ODHA, Sikap tetangga terhadap ODHA, Sikap tenaga kesehatan terhadap ODHA dan Sikap tokoh masyarakat terhadap ODHA. Faktor yang paling berpengaruh terhadap stigma masyarakat terhadap ODHA yaitu sikap tokoh masyarakat terhadap ODHA dengan nilai $\operatorname{EXP} \cdot B(O R)=4.834$ artinya tokoh masyarakat yang mempunyai sikap kurang terhadap ODHA mempunyai peluang memberikan stigma sebesar 4.834 kali lebih besar dibandingkan dengan tokoh masyarakat yang mempunyai sikap baik. Dari tujuh faktor yang berpengaruh di atas mempunyai probabilitas memberikan stigma terhadap ODHA sebesar $81.72 \%$.

\section{KEPUSTAKAAN}

Arikunto. 2000. Manajemen Penelitian. Jakarta : Rineka Cipta

BKKBN RI. 2012. Pedoman Pengelolaan Pusat Informasi Dan Konseling Remaja Dan Mahasiswa. BKKBN. Jakarta.

Debora, Imelda.,dkk. 2006. Kajian cepat Program Pencegahan Penularan HIV dari Ibu Ke Bayi. Edisi I. Cetakan ke-1. Puskadepkessos. FISIP- UI, YPI, ASSR- UvA. Puskadepkessos-UI. Jakarta

Green. G. 1995. Attitudes towards people with $H I V$ : Are they as stigmatizing as people with HIV perceive them to be. Social Science \& Medicine, 41(4), 557-568.

Goffman E. 1963. Stigma: Notes on the Management of a Spoiled Identity. Englewood Cliffs, NJ: Prentice Hall. Diakses dari Http://Www.Slideshare.Net/Hutaur ukmusa/Stigma-Dan-Diskriminasi. Pada pada tanggal 6 Desember 2013.

Green. L. 2000. Health Promotion Planning An Aducational And Environmental Approach. London. Mayfield Publishing Company. Eds.2.

Herek, G.M., Capitanio, J.P., Widaman, K.F. 2002. HIV-related stigma and knowledge in the United States: prevalence and trends, 1991-1999. Am. J. Public Health 92 (3), 371377.

Kemenkes. RI. 2007. Pedoman Pengembangan Jejaring Layanan Dukungan, Perawatan Dan 
Pengobatan HIV dan AIDS. Direktorat Jendral Pengendalian Penyakit Dan Penyehatan Lingkungan. Jakarta.

Kemenkes. RI. 2012. Buku Pedoman Penghapusan Stigma \& Diskriminasi Bagi Pengelola Program, Petugas Layanan Kesehatan Dan Kader. Kementerian Kesehatan RI Direktorat Jenderal Pengendalian Penyakit Dan Penyehatan Lingkungan Direktorat Pengendalian Penyakit Menular Langsung. Jakarta.

KPAD NTT. 2013. Laporan Kasus HIV/AIDS NTT Tahun 2012. KPAD NTT. Kupang

KPAD Kabupaten Manggarai Provinsi NTT. 2013. Laporan Kasus HIV/AIDS Tahun 2012. KPAD Kabupaten Manggarai. Ruteng.

Kaldor, J., at.all. 2000. Penilaian eksternal tentang HIV/AIDS ( external Assessment on HIV/AIDS). Dirjen. P2MPLP. Kemenkes.RI. Jakarta.

KPAN. 2011. Laporan Akhir Penelitian : Peran dukungan sebaya terhadap peningkatan mutu hidup ODHA di Indonesia tahun 2011. KPAN. Jakarta.

Lemeshow, S., Hosmer, D.W.,Jannele,K \& Lwanga S.K. 1997. Besar Sampel Dalam Penelitian Kesehatan. edisi bahasa Indonesia. Penerjemah : Dibyo Pramono. Diterbitkan dan dicetak oleh Gadjah Mada University press anggota IKAPI 9708093-C1E. Yogyakarta.

Major B. and O'Brien L.T. 2004. The Social Psychology of Stigma. Department Of Psychology. University Of California, Santa Barbara, Santa Barbara, California 93105`Annu.Rev.Psychol.2005.56: 393421.Doi:10.1146/Annurev.Psyc h.56.091103.070137 Copyright_C 2005 By Annual Reviews. All Rights Reserved First Published Online As A Review In Advance On September 14.

Nasronudin. 2007. HIV Dan AIDS : Pendekatan Biologi Molekuler, Klinis Dan Sosial. Air Langga University Press. Surabaya.

Notoadmojo, S. 2009. Pendidikan dan Promosi Kesehatan. Rineka Cipta. Jakarta

Nurgiyantoro B. 2009. Marzuki \& Gunawan. Statistik Terapan, Untuk Penelitian Ilmu-Ilmu Social. Gadjah Mada University Press, Yogyakarta

O'Connor, Pam, Ernest \& Jaya. 2011. Voices Of Resilience Stigma, Discrimination And Marginalisation Of Indian Women Living With HIV/AIDS. Curtin University, Western Australia. Sense Publishers,P.O. Box 21858,3001 AW Rotterdam, The Netherlands.

Paryati, T., Ardini S. R., \& Irvan A. 2013. Faktor-faktor yang Mempengaruhi Stigma dan Diskriminasi kepada ODHA(Orang dengan HIV/AIDS) oleh petugas kesehatan : kajian literature. Universitas Padjadjaran Bandung. Bandung.

Sally C.,Dkk. 2011. People Living With HIV Stigma Index Asia Pacific Regional Analysis. UNAIDS Report.

Sugiyono. 2010. Statistika untuk Penelitian. Alfabeta. Cetakan ke-11. Bandung.

UNAIDS. 2012. Key Programmes to Reduce Stigma and Discrimination and Increase Access to Justice in National HIV Responses. United nations : UNAIDS. Geneva.

UNAIDS. 2000. HIV and AIDS-related stigmatization, discrimination and denial: Forms, contexts and determinants. Research studies from 
Uganda and India (prepared for UNAIDS by Peter Aggleton). UNAIDS. Geneva

Wawan, A. dan Dewi, M. 2010. Teori dan Pengukuran Pengetahuan, Sikap dan Perilaku Manusia. Cetakan ke2. Nuha Medika. Yogyakarta.

Widyawati, M.N. 2009. Analisis FaktorFaktor yang mempengaruhi sikap ibu hamil terhadap HIV-AIDS dan VCT di Kelurahan Mangunharjo Kecamatan Tugu semarang tahun 2009. Tesis Magister Promosi Kesehatan FKM. Universitas Diponegoro. Semarang.

Wood, K., Aggleton, P., Malcolm, A., Parker, R. 2005. HIV- Related Stigma, Discrimination, and Human rights violation : case studies of successful programmes. Thomas Coram Research Unit. Institude of Education. University of London. United Kingdom. Geneva : Switzerland. UNAIDS.

Yuyun, Y, Rini,S.H dan Aryastami.N.K. 2011. Faktor - Faktor Pendukung Kepatuhan Orang Dengan HIV/AIDS (Odha) Dalam Minum Obat Antiretroviral Di Kota Bandung Dan Cimahi. Pusat Teknologi Intervensi Kesehatan Masyarakat, Badan Litbangkes, Pusat Humaniora, Pemberdayaan Masyarakat dan Kebijakan Kesehatan, Badan Litbangkes Buletin Peneliti Kesehatan. Vol. 41, No. 2, 2013: 72 - 83 73. Bandung. 